Syntax Fusion : Jurnal Nasional Indonesia

P-ISSN: $x x x x-x x x x$

E-ISSN : $x x x x-x x x x$

Vol. 1, No. 2, Februari 2021

\title{
POLA DAKWAH PADA ERA DISRUPSI (STUDI TERHADAP MAHASISWA KPI STAI PERSIS BANDUNG)
}

\author{
Muhammad Farhan Tamimi \\ STAI Persis Bandung \\ E-mail: Farhantamimi1997@gmail.com
}

\begin{abstract}
Abstrak
Perkembangan ilmu pengetahuan dan teknologi telah melahirkan sebuah revolusi di bidang industri. Dampak yang dihadirkan dari revolusi industri ternyata bukan hanya pada bidang industi maupun bidang ekonomi saja, melainkan berdampak pada semua bidang kehidupan di dunia. Lahirnya era disrupsi merupakan dampak dari hadirnya revolusi industri, sehingga melahirkan tantangan baru di dunia dakwah. Dari setiap tantangan baru yang hadir tentu harus ada juga pola baru dalam menyelesaikan tantangan itu, maka penelitian ini bertitik tolak dari sebuah kenyataan bahwa dunia kini sedang menghadapi era baru yang disebut era disrupsi. Tujuan dari penelitian ini pertama adalah untuk mengetahui terlebih dahulu minat dakwah mahasiswa KPI STAI Persis Bandung sehingga bisa menjadi titik tolak untuk mencari sebuah pola baru dalam dunia dakwah pada era disrupsi, sehingga kegiatan dakwah pada era disrupsi mampu menjadi counter dari dampak negatif lain di era disrupsi. Penelitian ini dilakukan dengan cara mengambil sumber data melalui observasi dan wawancara terhadap mahasiswa STAI Persis Bandung yang memang menjadi fokus penelitian, terlebih kepada mahasiswa STAI Persis Bandung yang memang fokus melakukan dakwah digital dari semua program studi yang ada di STAI Persis Bandung. Penelitian ini bersifat deskriptif kualitatif, metode ini dipandang lebih mampu menangkap berbagai informasi dengan kejelasan deskripsi yang lebih teliti dan penuh makna. Artinya mengumpulkan data-data yang akurat dan sederhana untuk dianalisis dengan cara berpikir logis baik induktif maupun deduktif. Sehingga mampu memberikan hasil yang akurat dan dapat dipertanggung jawabkan.
\end{abstract}

Kata Kunci: Revolusi Industri, Era Disrupsi, Pola Dakwah

\section{Pendahuluan}

Menjelang tahun 2020, Indonesia akan mengalami ledakan jumlah penduduk usia produktif. Badan Pusat Statistika (BPS) mengelompokkan penduduk usia produktif sebagai yang berusia 14-64 tahun. Pertama kalinya dalam sejarah, Indonesia akan 
mengalami ledakan jumlah penduduk usia produktif yang sangat tinggi. Dalam demografi, ledakan penduduk usia produktif tersebut dinamakan bonus demografi (Ali \& Purwandi, 2017, p. 27).

Bonus demografi tidak bisa dipisahkan dari generasi Milennial karena merekalah penyumbang terbesar bonus demografi di Indonesia. milennial adalah istilah cohort dalam demografi. Saat ini terdapat empat cohort besar dalam demografi, yaitu Baby Boomer, Gen-X, Milennial dan Gen-Z (Ali \& Purwandi, 2017). Milennial adalah mereka yang saat ini berperan sebagai mahasiswa, early jobber dan orang tua muda. Milennial saat ini (pada tahun 2017) adalah mereka yang berusia 17-34 tahun. Milennial lahir antara tahum 1981-2000 (Ali \& Purwandi, 2017).

Kemajuan ilmu pengetahuan telah menghasilkan teknologi yang semakin canggih dan membawa banyak perubahan. Perubahan yang disebabkan oleh kemajuan teknologi tidak hanya berdampak bagi perkembangan teknologi itu sendiri, akan tetapi juga mempengaruhi dalam kehidupan manusia, misalnya seperti cara berkomunikasi. Pada awalnya, manusia berkomunikasi secara berhadap-hadapan langsung (face to face) atau menggunakan alat dengan jangkauannya terbatas. Pesan yang disampaikan pun umumnya bersifat sederhana.

Dengan teknologi, telepon seluler yang awalnya hanya mempunyai fitur suara atau teks, saat ini dengan dilengkapi fitur suara, teks dan gambar yang dapat dilakukan dalam satu aktivitas sekaligus. Fungsi telepon seluler yang awalnya hanya sebagai alat komunikasi, pada saat ini sudah dapat disebut sebagai salah satu dari bagian diri manusia. Perubahan besar yang bersifat mendasar dan terjadi dengan sangat cepat tanpa bisa ditahan lajunya, oleh beberapa ahli disebut disrupsi (Hapsari, 2019, p. 152).

Kecanggihan teknologi yang kini masuk ke rumah-rumah warga yang salah satunya melalui Smartphone yang terkoneksi melalui internet memiliki sisi positif dan negatif, yang artinya perkembangan teknologi tersebut tidak menjamin sepenuhnya pengguna smartphone menjadi smartpeople. Generasi milenial menjadi sasaran empuk dalam era disrupsi ini, karena rata-rata generasi milenial di Indonesia sejak lahir sudah mengenal era digitalisasi, tidak seperti generasi-generasi sebelumnya yang merasakan betul proses terjadinya era disrupsi.

Atas fenomena tersebut, Rhenald Kasali dengan meminjam istilah Clayton M Chistenses menyebutnya fenomena tersebut dengan era Disruption atau dalam bahasa Indonesia disebut disrupsi (hal tercerabut dari akarnya). Rhenal Kasali menyebutkan bahwa era disrupsi ini menyuguhkan berbagai kemudahan dan keefektipan dalam mengerjakan sesuatu, Rhenald memeberikan contoh tentang Uber yang pertama kali ada di Amerika.

Disruptif pada awalnya merupakan fenomena yang terjadi dalam dunia ekonomi, khususnya di bidang bisnis. Clayton (Christensen, 1997), seorang Profesor Bisinis Harvard menyebutnya sebagai distruption innovative dalam The Innovator's Dilemma (Christensen, 1997). Disruptif sendiri merupakan kondisi ketika sebuah bisnis dituntut untuk terus berinovasi mengikuti perkembangan, sehingga bisnis tidak hanya untuk 
memenuhi kebutuhan-kebutuhan sekarang, namun dapat mengantisipasi kebutuhan di masa mendatang (Trisyanti, n.d., p. 22).

Ternyata perkembangan revolusi industri 4.0 sudah dirasakan oleh mahasiswa pada umumnya, tidak terkecuali oleh mahasiswa STAI Persis Bandung. Dampak dari revolusi industri 4.0 yang hampir mendisrupsi segala bidang kehidupan dengan menyuguhkan kemudahan mengakses melalui fitur digitalisasi ternyata sudah dirasakan oleh mahasiswa STAI Persis Bandung.

Penggunaan Smartphone bisa menjadi sebuah indikator masuknya era disrupsi dikalangan mahasiswa STAI Persis Bandung, bahkan salah satu metode pendaftaran yang diadakan oleh STAI Persis Bandung kini sudah bisa diakses melalui website resmi milik STAI Persis Bandung. Hal tersebut secara tidak langsung menggiring calon mahasiswa STAI Persis Bandung untuk mengakses internet, yang rata-rata media tempat mengakses internet itu dilakukan oleh Smartphone.

Makadari itu, revolusi industri yang menyebabkan hadirnya era disrupsi menyuguhkan pemandangan baru dalam berbagai aspek, salah satunya aspek dakwah. Menjadi landasan kuat untuk dilakukan penelitian tentang Pola Dakwah pada Era Disrupsi khususnya dikalangan mahasiswa KPI STAI Persis Bandung, karena mengingat program studi KPI merupakan program yang fokus pada kegiatan dakwah.

\section{Metode Penelitian}

Metode yang digunakan dalam penelitian ini adalah metode penelitian deskriktif kualitatif. Metode penelitian ini dipandang lebih mampu menangkap berbagai informasi dengan kejelasan deskripsi yang lebih teliti dan penuh makna. Penelitian kualitatif juga dipandang lebih mudah menyesuaikan diri dengan responden yang dijumpai dalam proses penelitian. Metode deskriktif kualitatif juga mendorong peneliti membangun hubungan yang baik dengan respoden guna mendapatkan informasi yang dibutuhkan dalam penelitian. Jenis data yang digunakan peniliti adalah bentuk wawancara terhadap mahasiswa KPI STAI Persis Bandung yang fokus pada kegiatan dakwah

\section{Hasil Dan Pembahasan}

\section{A. Minat Dakwah Mahasiswa KPI STAI Persis Bandung}

Kegiatan mahasiswa KPI STAI Persis Bandung tidak terlepas dari interaksi sosial baik dengan sesama mahasiswa lainnya ataupun dengan dosen. Interaksi yang dilakukan oleh mahasiswa KPI senantiasa menghadirkan suasana yang hangat dan damai, mulai dari mengobrol sampai berkegiatan.

Terkadang interaksi sosial yang dilakukan mahasiswa KPI STAI Persis Bandung berujung pada perbuatan yang positif, seperti selesai mengobrol pergi ke masjid, sampai dari hasil diskusi menghadirkan sebuah karya, seperti savana post, diksi, fotosfer dan lain sebaginya. Artinya dari interaksi yang dilakukan oleh mahasiswa KPI STAI Persis Bandung memiliki nilai dakwah, sehingga mampu memetakan minat dakwah mahasiswa KPI secara teristematis. 
Observasi yang dilakukan oleh peneliti dimulai selama peneliti berkuliah di STAI Peris Bandung sampai hari ini, sehingga pada akhir semester, peneliti akan menaikkan data tersebut menjadi data wawancara.

Pemaknaan beberapa mahasiswa STAI Persis Bandung terkait dakwah, sepakat bahwa dakwah merupakan sebuah seruan, $d a$ 'a, yad'u, $d a$ 'watan yang artinya menyeru, yakni amar ma'ruf nahi munkar, menyeru kepada kebaikan dan mencegah kepada kemunkaran. Menyampaikan risalah Allah yang telah diturunkan melalui Nabi Muhammad saw.

Disamping itu juga, beberapa narasumber menyebutkan bahwa dakwah juga merupakan sebuah proses, proses perubahan kearah lebih baik, perubahan dari perkataan kepada perbuatan. Hal ini disampaikan oleh Fahri Fauzan Azhari, mahasiswa KPI semester akhir, beliau menyampaikan bahwa "dakwah suatu kegiatan penyampaian nilainilai islam berupa akhlak, akidah, dan syariah. Ada juga yang menyampaikan bahwa dakwah juga sebagai tabligh, hanya berupa penyampaian. Padahal dakwah lebih dari itu, dakwah adalah sebuah proses, proses perubahan kearah yang lebih baik, dari munkar kepada ma'ruf, dari perkataan kepada perbuatan".

Pemaknaan mahasiswa STAI Persis Bandung terkait dengan dakwah tidak hanya cukup sampai disana. Ada juga beberapa mahasiswa yang menyebutkan bahwa dakwah merupakan sebuah implementasi dari sebuah pemikiran. Seperti yang dikatakan oleh salah satu mahasiswa KPI semester 7, Vina Rosalina, saat diwawancara melalu whatsapp. Vina menyebutkan bahwa "dakwah merupakan sebuah aksi heroik, jalan terbaik dalam berpikir untuk menyikapi hidup".

Pemaknaan terhadap dakwah itu sendiri ternyata masih saja dipahami sebagai kegiatan dari satu mimbar ke mimbar lainnya. Amirul Muttaqien mahasiswa IQT semester akhir menyebutkan bahwa dakwah pemahaman dakwah itu mesti diperluas, seperti menolong terhadap sesama juga merupakan sebuah kegiatan dakwah.

Hasil wawancara tersebut menunjukkan bahwa pemaknaan mahasiswa terhadap dakwah tidak hanya berhenti sampai tataran definisi, melainkan sudah mempu memodifikasi menjadi sebuah perbuatan atas dasar kesadaran pribadi dan kewajiban dalam berdakwah.

Kegiatan dakwah yang dilakukan mahasiswa KPI STAI Persis Bandung pada dasarnya terdorong oleh hadirnya HMJ KPI STAI Persis Bandung yang memiliki program kerja secara terstruktur dan sistematis, sehingga mendorong mahasiswa KPI untuk ikut dalam program kegiatan HMJ KPI yang notabene cenderung pada kegiatan diskusi dan belajar bersama.

Akan tetapi, beberapa mahasiswa KPI menyebutkan bahwa kegiatan dakwah di kalangan mahasiswa KPI STAI Persis Bandung cenderung tidak terasa, mungkin karena faktor pemaknaan terhadap dakwah yang kurang, atau memang dakwah yang dihadirkan belum begitu terasa oleh mahasiswa yang lainnya.

Beberapa pertanyaan yang sudah disusun oleh peneliti dalam menemukan data yang diinginkan dalam bab sebelumnya akan membantu terjawabnyan permasalahan yang diangakat, salah satunya adalah minat mahasiswa KPI STAI Persis Bandung dalam 
kegiatan dakwah. Sehingga dapat dijadikan sebagai tolak ukur dalam pengembangan SDM kedepannya.

Dari hasil wawancara beberapa mahasiswa KPI STAI Persis Bandung, tingkat minat dakwah mahasiswa KPI STAI Persis Bandung relatif berbeda namun memiliki nilai dakwah, mulai dari pendasaran pada kesadaran literasi sampai pada tingkat kesadaran pengembangan diri.

Beberapa minat dakwah mahasiswa KPI STAI Persis Bandung dari hasil wawancara dengan mahasiswa KPI disemua semester:

1. Kajian

Kajian merupakan salah satu kegiatan dakwah yang ada di lingkungan mahasiswa KPI STAI Persis Bandung yang terbilang diminati oleh mahasiswa KPI terkhusus oleh mahasiswa yang memiliki kesadaran akan literasi. Kajian tersebut juga sering diadakan oleh setiap tingkatan mahasiswa KPI dari setiap generasinya. Mulai dari generasi angkatan terdahulu, seperti angkatan tahun 2015, sampai angkatan yang 2018.

Salah satu mahasiswa KPI semester akhir, Muhammad Zaim Ukhrowi menyebutkan bahwa "secara kelembagaan internal mahasiswa KPI lebih cenderung kegiatan dakwah itu kepada pengembangan tingkat literasi, seperti kajian dan diskusi".

Disamping itu juga, kajian yang hadir sebagai bentuk peningkatan keilmuan mahasiswa KPI STAI Persis Bandung didukung juga oleh kegiatan yang ada di HMJ KPI STAI Persis Bandung seperti Kajian Rutin Mahasiswa (KARMA). KARMA itu sendiri diadakan rutin oleh HMJ KPI STAI Persis Bandung setiap hari rabu sehabis perkuliahan, materi yang dihadirkan pun relatif, mulai dari keagamaan samapi ke kajian filsafat.
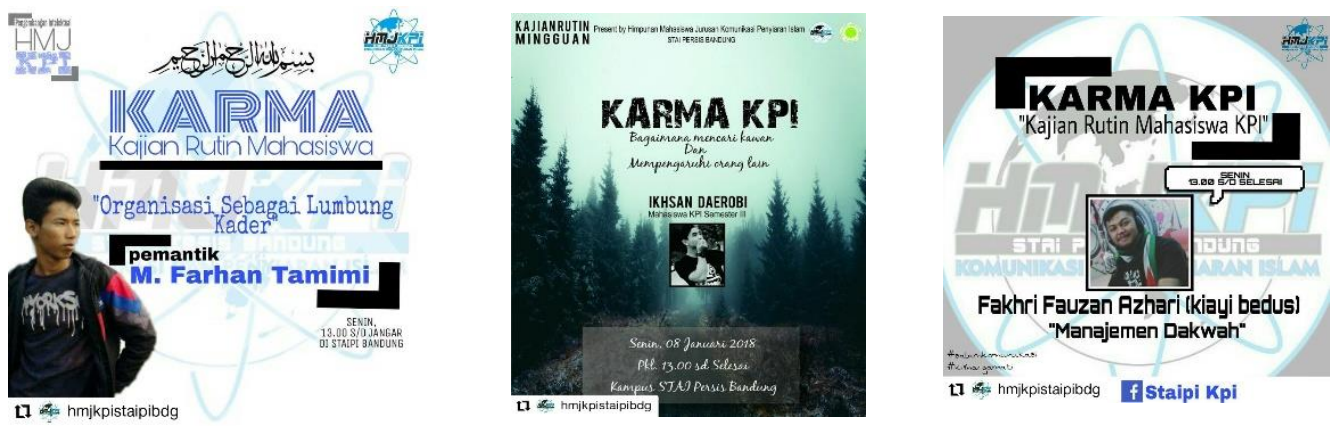

(Dokumen resmi milik HMJ KPI STAI Persis Bandung terkait KARMA. Sumber akunintagram @hmjkpistaipibdg)

Selain itu juga, minat mahasiswa STAI Persis Bandung terhadap kajian bukan hanya di lingkungan mahasiswa KPI STAI Persis Bandung saja, melainkan mengejarjuga kajian-kajian yang diadakan oleh mahasiswa prodi lain. Seperti yang sudah dilakukan oleh peneliti ketika mengobrol dengan beberapa mahasiswa KPI, bahwa mahasiswa KPI itu sering kali haus akan kajian, sehingga kajian yang diadakan oleh program studi lain dikejar. 
Selain kajian yang diadakan rutin oleh HMJ KPI, diskusi bertukar gagasan dan pemikiran diruang publik juga sering dilakukan oleh mahasiswa KPI dan diberange oleh mahasiswa lain dari prodi yang lain, seperti menggelar tikar untuk berdiskusi, sampai menyediakan buku bacaan gratis untuk mahasiswa STAI Persis Bandung dalam rangka mengajak untuk membaca.

Dengan demikian, tingkat minat mahasiswa STAI Persis Badung terhadap dakwah melalui kajian sangat tinggi.

\section{Dakwah bil-Lisan}

Dari hasil wawancara pada mahsiswa KPI STAI Persis Bandung menunjukkan bahwa dakwah bil-lisan sangat melekat pada diri setiap mahasiswa STAI Persis Bandung, seperti sapa tegur, menasehati, mengajak kepada kebaikan, dan lain sebagainya.

Seperti yang telah dikatakan oleh Ghinanti salah satu mahasiswa KPI semeter akhir saat diwawancarai, "kegiatan dakwah mahasiswa KPI salah satunya adalah dakwah bil-lisan, baik disadari atau tidak, ketika dikelas tidak sedikit yang saling menegur ketika melakukan salah, kadang juga mengajak kepada kebaikan, seperti pergi ke masjid dan sebagainya".

Kegaiatan dakwah bil-lisan lebih cenderung kepada dakwah secara spontan, dakwah secara spontan itu maksudnya adalah dakwah yang dilakukan tanpa ada rencana sebelumnya, contohnya menegur ketika ada yang berbuat salah, mengajak ke masjid ketika adzan berkumandang, menyuruh membuang sampah pada tempatnya, dan banyak lagi. Seperti yang dikatakn oleh ketua HMJ KPI periode 2019-2020, Indra. Indra mengatakan bahwa "banyak mahasiswa yang saya perhatikan melakukan dakwah bil-lisan, baik mereka sadar atau tidak, yang pokok adalah nilai-nilai dakwah disampaikan, seperti mengajak ke majid, sampai mengajak tadarus al-Qur'an sebelum perkuliahan dimulai”.

Dari hasil penelitian ini, setidaknya bisa kita ketahui bahwa kegiatan dakwah di kampus STAI Persis Bandung, khususnya dilingkungan mahasiswa KPI begitu kental, menunjukkan bawha tingkat pemaknaan dakwah sangat tinggi, sehingga bisa terimplementasi kepada suatu gerakan konkrit.

\section{Dakwah Melalui Tulisan}

Dakwah melalui tulisan merupakan salah satu minat dari kegiatan dakwah mahasiswa KPI STAI Persis Bandung. Salah satu mahasiswa KPI semester akhir, Muhammad Asfi, "salah satu minat dakwah mahasiswa KPI diimplementasikan melalui tulisan". Beberapa mahasiswa KPI STAI Persis Bandung tercatat sebagai penulis aktif dibeberapa media cetak yang ada di kampus bahkan ada yang sudah menerbitkan buku.

Dalam wawancara bersama Asfi menyebutkan bahwa "hadirnya Savana Post dulu menjadi media dalam penyaluran tulisan bagi mahasiswa STAI Persis Bandung, khususnya bagi mahasiswa KPI yang lebih intens membicarakan terkait tulisan". Selain itu juga, Fahri Fauzan Azhari menyebutkan "bahwa hadirnya diksi di HMJ KPI adalah untuk menjadi media penyalur tulisan bagi mahasiswa KPI khususnya. Karena 
melalui tulisan orang bisa bebas menuliskan beberbagai perasaan yang kemudian dituangkan menjadi sebuah tulisan".

Mahasiswa KPI lainpun menyebutkan hal demikian, hadirnya diksi, savana post dan media cetak lainnya membuktikan bahwa minat mahasiswa STAI Persis Bandung terhadap tulisan sangat tinggi.

Beberapa Mahasiswa KPI STAI Persis Bandung yang pernah aktif menulis dalam konteks dakwah.

a. Hanasuddin, mahasiswa KPI angkatan 2013. Hasan pernah aktif menulis beberapa tulisan yang memuat tentang ajakan berliterasi dan Hasan juga merupakan pendiri dari Savana Post (Koran Kampus).

b. Mahasiswa KPI STAI Persis Bandung angkatan 2015, pernah membuat buku tentang Bunga Rampai Ilmu Alamiah Dasar pada tahun 2016

c. Vina Rosalina, mahasiswa KPI angkatan 2016. Vina sampai saat ini aktif menulis di savanapost.com tentang berbagai konten salah satunya konten dakwah yang berjudul "Memahami Keragaman Agama-Agama Manusia".

d. Fahri Fauzan Azhari, mahasiswa KPI angkatan 2015. Pada tahun 2019 Fari telah berhasil menerbitkan buku yang berjudul "Nak-Nak 06" dan sekrang sedang menggarap buku yang kedua.

e. Deffa Hudzaifa, mahasiswa KPI angkatan 2017. Deffa pernah menulis di website savanapost.com yang berjudul "Untuk Apa Kuliah?".

f. Alvian Hamzah, mahasiswa KPI angkatan 2016. Alvian pernah aktif menulis di buletin HMJ KPI yakni Diksi dan sekarang Alvian aktif menulis di bipol.co.

4. Dakwah melalui Radio

Salah satu fasilitas yang dimiliki prodi KPI adalah fasilitas radio, tidak sedikit mahasiswa yang memanfaatkan fasilitas itu untuk berlatih menjadi penyiar radio. Terkadang dalam latihan yang dilakukan oleh mahasiswa KPI STAI Persis Bandung membawakan materi tentang konten dakwah, seperti keutamaan sholat diawal waktu, keutamaan menuntut ilmu dan lain sebagainya.

\section{B. Kegiatan Dakwah pada Era Disrupsi di Kalangan Mahasiswa KPI STAI Persis Bandung}

Penggunaan teknologi digital, sebut saja smartphone yang merupakan salah satu prodak dari hadirnya era disrupsi di kalangan mahasiswa STAI Persis Bandung melihat hasil observasi dari peneliti mulai kuliah begitu tinggi, berbagai kebiasaan dilakukan oleh mahasiswa KPI STAI Persis Bandung dengan smartphonenya, baik dalam cara berkomunikasi, eksistensi, sampai bermain game.

Namun ada beberapa mahasiswa yang dengan smartphonenya melakukan hal yang bermanfaat, seperti men-share video dakwah hingga digunakan untuk mengedit video. Tidak sedikit juga mahasiswa KPI yang melengkapi alat digitalnya untuk mendukung kelancarannya di bidang digital. Seperti salah satu mahasiswa KPI semester 5 yang suka membuat film pendek bertemakan dakwah. 
Minat dakwah mahasiswa KPI STAI Persis Bandung terhadap dakwah ternyata tidak sampai disana, hadirnya era disrupsi yang menghadirkan perkembangan teknologi digital sudah disadari oleh mahasiswa KPI secara keseluruhan, contohnya kecil saja seperti penggunaan smartphone yang tinggi, hingga berbagai konten positif dan negatif yang dihadirkan oleh perkembangan teknologi digital.

Tingkat penggunaan smartphone di kalangan mahasiswa KPI STAI Persis Bandung sendiri terbilang sangat tinggi mulai dari angkatan 2015 samapi angkatan 2018, bahkan mungkin tidak ada mahasiswa yang tidak memiliki smartphone.

Seperti yang dilansir oleh CNN Indonesia melalui wawancara bersama Wakil Kepala Kepolisian RI Komisaris Jenderal Syafruddin pada 17 juli 2018 bahwa Indonesia tercatat sebagai negara kedua dengan tingkat kejahatan cyber di dunia. Kementrian Komunikasi dan Informatika (Kemkominfo) telah memblokir seanyak 800 ribu situs penyebar hoax di internet sepanjang tahun 2015.

Data diatas menunjukkan bahwa dampak dari hadirnya era disrupsi dengan prodak teknologi digital sangat tinggi, baik kejahatan secara langsung yang menyerang fisik, atau serangan secara tidak langsung menyerang terhadap kejiwaan manusia.

a. Pelaku Dakwah Digital pada Era Disrupsi di Kalangan Mahasiswa KPI STAI Persis Bandung

Muhammad Asfi menjelaskan bahwa "era disrupsi bukan hanya sebatas masalah ekonomi saja, lebih jauh hadirnya era disrupsi merupakan sebuah perang, perang melawan konten-konten negatif, perang melawan paham yang menyimpang, dan perang melawan kebobrokan moral. Mahasiswa KPI khususnya yang fokus pada bidang dakwah harus masuk pada ranah itu, menjadi sebuah tameng bagi umat Islam dengan menghadirkan konten-konten yang positif'.

Ghinanti seorang mahasiswi KPI angkatan 2015 yang juga aktif di dakwah digital melalui instagram menyebutkan bahwa "setiap aktifitas yang bernilai positif itu merupakan dakwah, nah kemudian meliaht konteks sekarang, tidak sedikit orang dengan aktifitas yang menyimpang dengan ajaran Islam berani untuk menggunggah kemedia sosial dan mempengaruhi orang lain lewat unggahannya. Lalu kenapa kita tidak berani?. Terkadang apa yang kita sampaikan akan sangat berguna bagi orang lain.”.

Dalam hal ini, Muhammad Zaim Ukhrawi menjelaskan bahwa "dalam konteks era disrupsi, mahasiswa KPI khususnya bisa memanfaat perkembangan teknologi digital sebagai media dakwah baru, seperti YouTube, Intagram, Facebook, Twitter, Whatsapp dan media sosial lainnya". Selain itu juga Deffa Hudzafa mahasiswa KPI semster 5 menyebutkan bahwa "minat masyarkat Indonesia terhadap audio visual terbilang tinggi sehingga menjadi peluang bagi mahasisa KPI untuk masuk pada ranah dakwah digital".

Ketua HMJ KPI STAI Persis Bandung, Indra menyebutkan bahwa "dalam dakwah digital, HMJ KPI sedang berusaha mendorong mahasiswa KPI untuk aktif dalam dakwah digital, dan menghimbau agar mahasiswa KPI mampu menggunakan media sosial dengan sebaik-baiknya dan sebijak-bijaknya. HMJ KPI sendiri sudah mulai melakukan dakwah digital, pada beberapa bulan lalu sebelum libur semesteran HMJ KPI sudah sudah 
menerbitkan tiga video pendek tentang pengamalan hadits-hadits pendek riwayat Bukhori yang kemudian di posting melalui intagram HMJ KPI, @hmjkpistaipibdg”.

Dengan demikian, merujuk data yang sudah didapatkan selama penelitian, pola dakwah pada era disrupsi bisa di spesifikasikan menjadi:

- Dakwah dengan film pendek

- Dakwah dengan tulisan

- Dakwah dengan gambar

- Dakwah dengan video pendek

Media yang dapat juga digunakan untuk mendukung terselenggaranya dakwah digital di era disrupsi diantaranya:

- YouTube

- Instagram

- Whatsapp

- Website

b. Manfaat dari Dakwah Digital

Pelaksanaan dakwah digital yang dilakukan oleh mahasiswa KPI STAI Persis Bandung di atas tentu tidak hanya bertujuan untuk kemaslahatan orang lain saja, tetapi memiliki nilai kebermanfaatan untuk diri sendiri.

1) Manfaat untuk Penikmat

Tuntunya bagi penikmat dakwah digital akan memberikan sekali manfaat, mulai dari materi dakwah sampai kemudahan untuk mengakses tentang dakwah.

Salah satu mahasiswa KPI sering mendengarkan beberapa tausyiah dari Ust. Adi Hidayat, Hanan Attaki, Evi Evendi dan ustad-ustad lainnya yang aktif pada kegiatan dakwah digital, menyebutkan bahwa konten dakwah-dakwah seperti itu sangat memberikan manfaat, seperti ketengan jiwa, termotivasi, dan tentunya menjadi pengingat disetiap aktifitas. Hal tersebut dijelaskan oleh Thariq Anbiya mahasiswa semester akhir.

2) Manfaat untuk Pelaku

Kebermanfaat dakwah digital tentunya saja tidak hanya dirasakan bagi para penikmatnya saja, bagi para pelaku dakwah digital juga memberikan manfaar yang besar. Ghinanti ketika diwawancarai menyebutkan bahwa dakwah digital yang dilakukannya ternyata memberikan manfaat yang banyak, dakwah yang disampaikan juga menjadi pengingat untuk dirinya sediri, "Inan ketika hendak mengunggah photo yang memperlihatkan nilai-nilai dakwah terkadang menjadi pengingat bagi diri Inan sendiri”

Selain menjadi pengingat bagi diri pelaku dakwah, ternyata melakukan dakwah digital juga sebagai kegiatan untuk melatih skil dalam mengedit video atau film dan itu menjadi kebanggaan tersendiri. Seperti yang dikatan oleh Yunus Isnain, "saya melakukakan dakwah digital bukan karena hanya sekedar melakukan, melainkan sebuah hobi dalam mengedit film atau video. Jadi saya merasa keahlian saya bisa berguna bagi orang lain". 
Sebetulnya, konteks dirupsi merupakan sebuah konteks yang berkaitan erat dengan ekonomi. Ketika peneliti melakukan wawancara bersama para pelaku dakwah digital dan mempertanyakan terkait kebermanfaatan dakwah digital terhadap pemasukan finansial, para pelaku dakwah digital malah memberikan tanggapan yang luar biasa.

Muhammad Zaim Ukhrowi salah satu pelaku dakwah digital menyebutkan bahwa "memang tidak setidik para YouTubers yang aktif salah satu kejarannya adalah urusan finansial. Namun dalam konteks dakwah, semuanya tidak bisa dihitung berdasarkan finansial saja. Saya melakukan dakwah online bukan saya yang tampil di layar, melainkan orang lain, saya hanya mengedit. Namun ketika saya melakukan itu, saya merasakaan manfaat yang luar biasa, saya bisa dikenal banyak orang dengan hasil editan saya, dan tidak sedikit yang memberikan pekerjaan untuk mengedit video lainnya".

Selain Zaim juga, Ghinanti hampir menyebutkan hal yang sama "dari hasil Inan melakukan dakwah digital, Inan tidak mengharapkan imbalan berupa materi. Tapi alhamdulillah, selama Inan aktif di dakwah digital, Inan dikenal banyak orang dan tidak sedikit orang yang mengundang Inan untuk mengisi beberapa kajian dan seminar, sehingga dari sana selalu ada pemasukkan secara finansial"

Dengan demikian, pelaksanaan dakwah pada era disrupsi yang menggunakan media digital sebagai alat untuk menyalurkannya akan memberikan manfaat yang banyak, baik bagi penikmat maupun bagi pelaku. Dan kebermanfaatan itu bagi para pelaku bukan hanya diukur dari tingkat pendapatan, melainkan dari tingkat keberkahan.

\section{Penutup}

Berdasarkan hasil analisi dari data yang diperoleh melalui penelitian dan dijelaskan pada bab sebelumnya, maka dapat ditarik kesimpulan sebagai berikut:

1. Minat dakwah mahasiswa KPI STAI Persis Bandung didasari pada tingginya tingkat literasi yang ada di kalangan mahasiswa STAI Persis Bandung sehingga mampu memodifikasi menjadi sebuah kegiatan yang bernilai dakwah, seperti (1) Kajian, (2) menulis, dan (3) pelatihan broadcasting. Selain itu juga, intensitas kegiatan yang berujung pada kegiatan dakwah melahirkan suatu keharmonaisan dalam berinteraksi yang pada aknhirnya dakwah bil-lisan dikalangan mahasiswa KPI STAI Persis Bandung terus digelorakan.

2. Perkembangan ilmu pengetahun dan teknologi yang telah melahirkan era disrupsi sudah disadari oleh sebagain mahasiswa KPI STAI Persis Bandung. Sehingga untuk menjadi counter dari dampak negatif yang dihadirkan oleh era disrupsi, beberapa mahasiswa KPI STAI Persis Bandung mulai memanfaatkan perkembangan teknologi sebagai media dakwah baru dalam menyikapi perkembangan zaman. Seperti memanfaatkan YouTube, Instagram, Whatsapp dan lain sebagainya. Dakwah pada era disrupsi berupa (1) Film/Video Pendek, (2) tulisan, (3) gambar, dan (4) membagikan video yang bermanfaat. Dari dakwah digital yang sudah dilakukan beberapa mahasiswa KPI STAI Persis Bandung 
ternyata meningkatkan minat mahasiswa KPI lainnya untuk bisa mempelajari tekni penguasaan teknologi digital.

\section{Bibliografi}

Ahmad Amrullah, ed. Dakwah dan Perubahan Sosial, (Yogyakarta: Prima Duta, 1983) Ali, H., \& Purwandi, L. (2017). Milenial nusantara. Gramedia Pustaka Utama.

Hapsari, D. (2019). Tantangan Perpustakaan Perguruan Tinggi Di Era Disrupsi. 11(1 Juni 2019), 152.

J. Moleong Lexi, Metodologi Penelitian Kualitatif(Bandung: Remaja Rosdakarya, 2008)

Trisyanti, B. P. dan U. (n.d.). Revolusi Industri 4.0 dan Tantangan Perubahan Sosial, (Institut Teknologi Sepuluh Nopember, Prosiding SEMATEKSOS 3 "Strategi Pembangunan Nasional Menghadapi Revolusi Industri 4.0. 22. 